\title{
Open Galeazzi fracture with ipsilateral elbow dislocation
}

\author{
Açık Galeazzi kırığı ile birlikte aynı taraf dirsek çıkığı
}

Oktay Adanır, MD., Serdar Yüksel, MD., Ozan Beytemur, MD., M. Akif Güleç, MD.

Department of Orthopedics and Traumatology, Bağcılar Training and Research Hospital, İstanbul, Turkey

\begin{abstract}
Combination of the Galeazzi fracture and dislocation of the elbow joint in same extremity is very rare. In this article, we report a 26-year-old male patient with a posterolateral dislocation of the elbow and ipsilateral volar type Galeazzi fracture. We performed closed reduction for the elbow dislocation during admission to the emergency department. Patient was taken to the operating room in the sixth hour of his application to emergency department and open wound on the ulnovolar region of the wrist was closed primarily after irrigation and debridement. We performed open reduction and internal fixation of the radial fracture with a dynamic compression plate. After fixation, we evaluated the stability of the elbow joint and distal radioulnar joint. Distal radioulnar joint was unstable under fluoroscopic examination and fixed with one $1.8 \mathrm{~mm}$ Kirschner wire in a pronated position. Then, elbow joint was stable. One year after surgery, patient had no pain or sings of instability. At the last follow-up, range of motion of the elbow was $10^{\circ}-135^{\circ}$ and forearm pronation and supination were $70^{\circ}$.
\end{abstract}

Keywords: Elbow joint; forearm injuries; Galeazzi fracture; radius.

A Galeazzi fracture has been described as a fracture of radial shaft combined with dislocation of the distal radioulnar joint (DRUJ). ${ }^{[1]}$ This injury accounts for $6.8 \%$ of forearm fractures in adults. ${ }^{[2]}$ Elbow dislocation is also a common injury type and accounts $11-28 \%$ of all elbow injuries. ${ }^{[3]}$ We report a patient who suffered a combination of the Galeazzi fracture and dislocation of the elbow joint in the same extremity, because it is very rare. ${ }^{[4]}$ Only seven cases have been reported in the literature which was written in English. ${ }^{[5-11]}$

\section{$\ddot{O Z Z}$}

Galeazzi kırı ̆̆ 1 ile birlikte aynı ekstremitede dirsek çıkı̆̆1 kombinasyonu oldukça nadir görülmektedir. $\mathrm{Bu}$ yazıda, posterolateral dirsek çıkı̆̆ı ile birlikte aynı taraf volar tip Galeazzi kırığı olan 26 yaşında bir erkek hasta sunuldu. Dirsek çıkığına acil bölümüne başvuru anında kapalı redüksiyon uygulandı. Hasta acil bölümüne başvurusunun altıncı saatinde ameliyathaneye alındı ve el bileği ulnar bölgedeki açık yara irrigasyon ve debridmanın ardından primer olarak kapatıldı. Radius kırığına dinamik kompresyon plağı ile açık redüksiyon ve internal fiksasyon uyguland1. Fiksasyonun ardından, dirsek eklemi ve distal radioulnar eklem stabilitesi değerlendirildi. Distal radioulnar eklem floroskopik inceleme altında dengesiz idi ve yüzüstü pozisyonda $1.8 \mathrm{~mm}$ Kirschner teli ile fikse edildi. Sonrasında, dirsek eklemi dengeli idi. Cerrahiden bir y1l sonra, hastanın ağrısı ve instabilite bulgusu yoktu. Son takipte, dirsek hareket açıklığ $10^{\circ}-135^{\circ}$, ön kol pronasyonu ve supinasyonu $70^{\circ}$ idi.

Anahtar sözcükler: Dirsek eklemi; ön kol yaralanmaları; Galeazzi kırığı; radius.

\section{CASE REPORT}

A 26-year-old male sustained right elbow and forearm injuries following a fall while playing football. He stated that he had fallen on his outstretched right arm. An initial clinical examination revealed a deformity of the elbow and forearm. There was a $5 \mathrm{~cm}$ wound on the ulna volar side of the wrist and the ulnar head was exposed. The neurovascular examination was normal. Radiographs of the forearm showed an oblique fracture of radial shaft at the junction of

- Received: March 24, 2015 Accepted: July 02, 2015

- Correspondence: Serdar Yüksel, MD. Bağcılar Eğitim ve Araştırma Hastanesi, Ortopedi ve Travmatoloji Kliniği, 34200 Bağcılar, İstanbul, Turkey. Tel: +90 536 - 3107468 Fax: +90 212 - 4404242 e-mail: serdar84yuksel@gmail.com 
distal and middle thirds, volar dislocation of the ulnar head and posterolateral dislocation of the elbow (Figure 1a, b). Immediate manipulation and reduction of the elbow dislocation was performed in the emergency department, the wound was covered with a sterile dressing and a long arm splint was applied (Figure 1c). Antibiotic treatment with a first generation cephalosporin was started in the emergency room and tetanus prophylaxis was also administered. The patient was taken to the operating room six hours after he arrived at the emergency department. Under general anesthesia, the patient's wound was irrigated with saline, debrided then closed primarily. During the same surgery, the radial shaft fracture was fixed using dorsal Thompson approach. Using a sterile tourniquet, a dorsal longitudinal skin incision was made over the fracture level. The radial border of the extensor digitorum communis was exposed, then an interval was developed between this muscle and extensor carpi radialis brevis muscle and they were both retracted to the ulnar and radial sides. The abductor pollicis longus muscle was also retracted distally and toward the ulna and posterior surface of the radius until the fracture line was reached. After anatomical reduction, internal
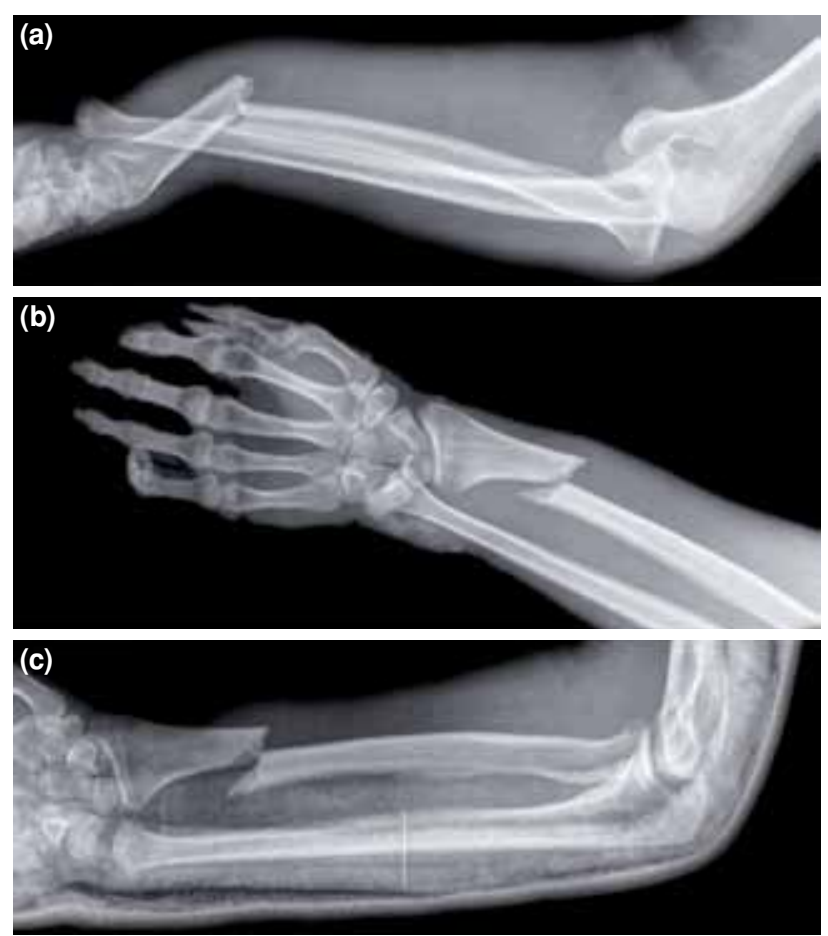

Figure 1. (a) X-ray of the right forearm showing both elbow dislocation and Galeazzi fracture. (b) Anteroposterior radiography of the wrist showing distal radioulnar joint dislocation and radius shaft fracture. (c) X-ray of the right forearm showing the closed reduction by immediate manipulation of both elbow and distal radioulnar joint. fixation of the radial shaft fracture was done using a $3.5 \mathrm{~mm}$ seven-hole locking compression plate. After internal fixation, the stability of the elbow joint and DRUJ was examined. Elbow joint stability was checked by looking at the range of motion of the elbow joint. It was fully flexed then extended slowly until dislocation occurred. Because it was not dislocated between 30-130 degrees of flexion, it was accepted as stable. The DRUJ was unstable under floroscopic examination and fixed with one $1.8 \mathrm{~mm}$ Kirchner wire (K-wire) in a pronated position (Figure 2a). The extremity was immobilized in a long arm splint with the elbow at $90^{\circ}$ flexion (Figure $2 \mathrm{~b}, \mathrm{c}$ ). After two weeks, the long arm splint was removed and gradual active flexion and extension exercises of the elbow joint were started with a limited motion brace. After six weeks, the K-wire was removed from the DRUJ then pronation and supination exercises commenced. One year after surgery, he had no pain or clinical evidence of instability. Final radiographs demonstrated normal elbow and wrist joints with a healed fracture of the radial shaft (Figure 3). Range of motion was $10^{\circ}-135^{\circ}$ at the elbow and $70^{\circ}$ pronation and $70^{\circ}$ supination at the forearm (Figure 4a-e). The patient was informed that data would be used for
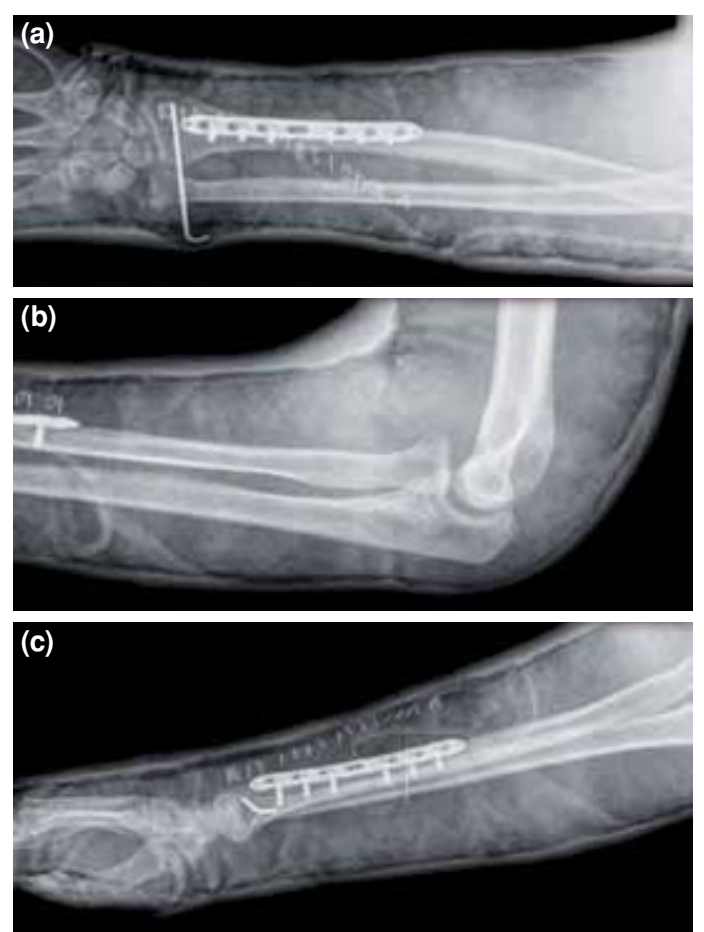

Figure 2. (a) Postoperative anteroposterior radiography of the right forearm showing distal radioulnar joint fixation with $\mathrm{K}$-wire and plate osteosynthesis of the radial diaphyseal fracture. (b) Postoperative elbow lateral radiography. (c) Postoperative wrist lateral radiography. 

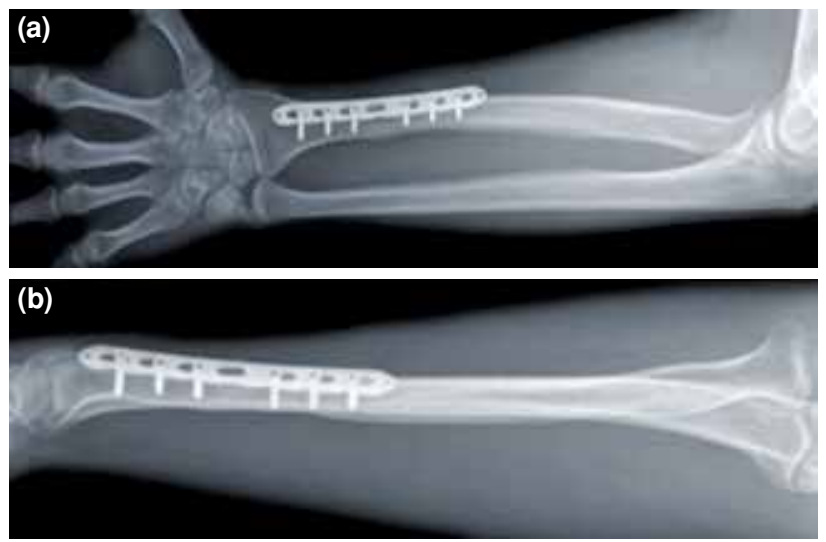

Figure 3. Anteroposterior and lateral radiography of the right forearm at the 12 month follow-up appointment.

publication and a written informed consent was obtained from the patient.

\section{DISCUSSION}

Galeazzi fracture is a common injury accounting for $6.8 \%$ of forearm fractures in adults. ${ }^{[2]}$ However a combination of Galeazzi fracture with elbow dislocation in the same extremity is very rare. A review of the English literature found only seven cases. ${ }^{[5-11]}$

It has been suggested that this injury occurs when causative energy is high or the position of the extremity at the time of impact is unique. ${ }^{[5,8]}$

The most common mechanism of Galeazzi fracture is a fall on the outstretched arm combined with extreme pronation. ${ }^{[1]}$ However Galeazzi fracture can be divided into two types: apex volar and apex dorsal. In apex volar type; distal radial fragment displaced dorsally (apex of the angulation is volar) and ulna is dislocated to the volar. In apex dorsal type; distal radial fragment displaced volarly (apex of the angulation is dorsal) and ulna is dislocated to the dorsal. Axial loading of the forearm in supination results in an apex volar type and axial loading in pronation results in an apex dorsal type fraction. ${ }^{[1]}$ The frequency of apex volar type when compared with apex dorsal type is much lower in Galeazzi fractures occurring in adults. ${ }^{[8]}$ The mechanism for posterolateral elbow dislocation is valgus and posterolateral rotational force acts on an outstretched arm, where as the mechanism for posteromedial dislocation is varus and posteromedial rotational force acts on an outstretched arm. ${ }^{[5]}$

Our patient could not remember the exact mechanism of the injury. He only told us that he had fallen on his outstretched hand while playing football and his arm remained under his body. He presented with an apex volar type Galeazzi fracture. We believe that the mechanism of injury is very similar to the case described by Asadollahi et al..$^{[5]}$ Axial loading to the supinated outstretched arm with the body weight of the patient acting as a driving force resulted in a Galeazzi fracture. After the radius fracture, the continuation of the axial force was transmitted through the intact ulna and caused elbow dislocation.

High energy trauma is the cause for most cases described in the literature. The only case described by Asadollahi et al. ${ }^{[5]}$ was caused by a low energy trauma. Our case was also a result of a relatively high energy sports trauma which caused an open Galeazzi fracture and ipsilateral elbow dislocation. Several of the cases which were described in the literature had (a)

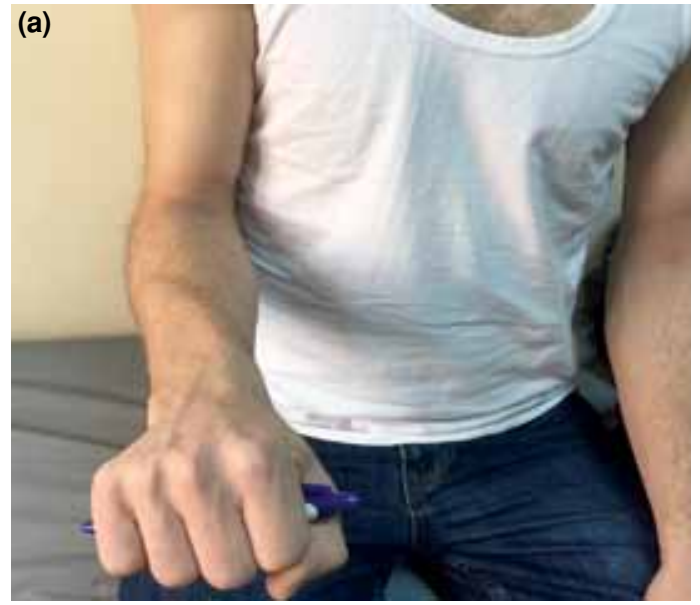

(b)

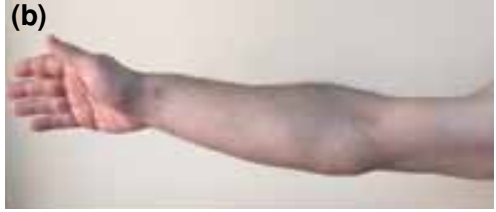

(c)

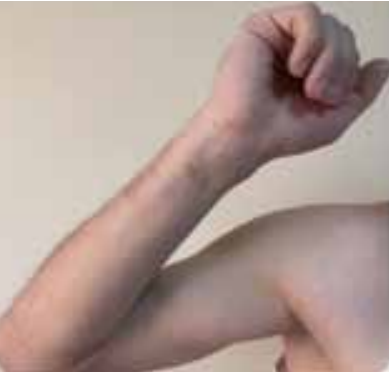

(d)

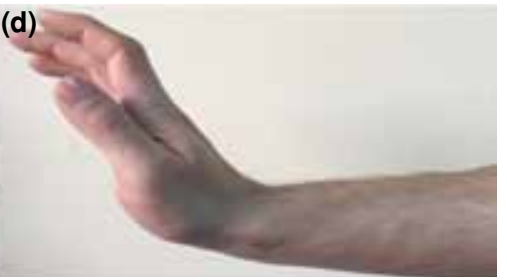

(e)

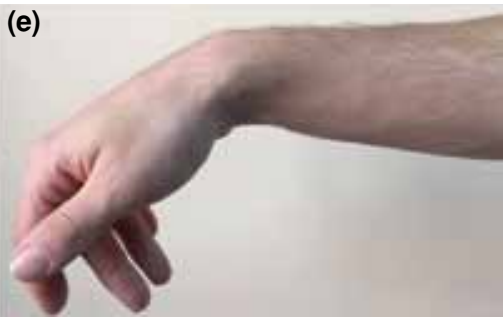

Figure 4. Photographs showing the functional range of motion of the patient at the 12 month follow-up appointment. 
TABLE I

Literature review of elbow dislocations and ipsilateral Galeazzi fractures

\begin{tabular}{|c|c|c|c|c|c|}
\hline Author & Age/Gender & Cause & Associated injury & $\begin{array}{l}\text { Treatment of Galeazzi } \\
\text { fracture }\end{array}$ & $\begin{array}{c}\text { Treatment of Elbow } \\
\text { dislocation }\end{array}$ \\
\hline Mezzadra et al. ${ }^{[6]}$ & $16 / \mathrm{M}$ & Motorcycle accident & $\begin{array}{l}\text { Ipsilateral ulna } \\
\text { fracture }\end{array}$ & Radial plate & Closed reduction \\
\hline Sarup and Bryant ${ }^{[10]}$ & $35 / F$ & Fall from stairs & $\begin{array}{l}\text { Ipsilateral humeral } \\
\text { fracture }\end{array}$ & Radial plate & Closed reduction \\
\hline Shiboi et al. ${ }^{[8]}$ & $34 / M$ & Fall from height & - & Radial plate & Closed reduction \\
\hline $\mathrm{Ng}$ and Rose ${ }^{[11]}$ & $27 / \mathrm{M}$ & Car accident & $\begin{array}{l}\text { Radial head and } \\
\text { coronoid fracture }\end{array}$ & $\begin{array}{l}\text { Radial plate and } \\
\text { DRUJ pinning }\end{array}$ & Open reduction \\
\hline Nanno et al..$^{[9]}$ & $32 / \mathrm{M}$ & Motorcycle accident & Scaphoid fracture & $\begin{array}{l}\text { Radial plate and } \\
\text { tension band of ulna } \\
\text { styloid fracture }\end{array}$ & Closed reduction \\
\hline Rajeev et al..$^{[7]}$ & $26 / M$ & Motorcycle accident & - & Radial plate & Open reduction \\
\hline Asadollahi et al..$^{[5]}$ & $58 / F$ & Fall while running & Radial head fracture & $\begin{array}{l}\text { Radial plate and } \\
\text { DRUJ pinning }\end{array}$ & Open reduction \\
\hline
\end{tabular}

DRUJ: Distal radioulnar joint.

additional injuries such as ipsilateral humerus shaft fracture, scaphoid fracture or radial head fracture but none of them was an open injury. ${ }^{[5,9,10]}$ The review of the literature demonstrates that in all seven cases, the Galeazzi fractures were treated successfully with open reduction and internal fixation. In five cases, the elbow dislocations were treated with closed reduction, the other two were treated with an open reduction (Table I). Shiboi et al. ${ }^{[8]}$ described a case where there was a lacerated $1 \mathrm{~cm}$ wound at the ulnovolar wrist region, but they did not classify their injury as open.

Treatment of Galeazzi fracture or elbow dislocation does not change because they occurred concurrently. ${ }^{[11]}$ In adults, open reduction rigid internal fixation and anatomical reduction of the distal radioulnar joint is standard care for Galeazzi fractures. Stability and reducibility of the DRUJ is commonly evaluated during surgery. If DRUJ is not reduced or not stabilized after reduction further surgical intervention may be necessary. ${ }^{[1]}$ Acute simple elbow dislocations can be treated with closed reduction. Complex elbow dislocations which are unstable or fracture dislocations may need surgery. Ipsilateral Galeazzi fracture and elbow dislocation is a rare injury and likely is a result of a high energy trauma. Attaining the expected outcomes after treatment does not change in the presence of concurrent occurrence.

\section{Declaration of conflicting interests}

The authors declared no conflicts of interest with respect to the authorship and/or publication of this article.

\section{Funding}

The authors received no financial support for the research and/or authorship of this article.

\section{REFERENCES}

1. Atesok KI, Jupiter JB, Weiss AP. Galeazzi fracture. J Am Acad Orthop Surg 2011;19:623-33.

2. Moore TM, Klein JP, Patzakis MJ, Harvey JP Jr. Results of compression-plating of closed Galeazzi fractures. J Bone Joint Surg [Am] 1985;67:1015-21.

3. Hobgood ER, Khan SO, Field LD. Acute dislocations of the adult elbow. Hand Clin 2008;24:1-7.

4. Bağatur AE, Yalçınkaya M. How to write a case report? or... not write at all? Eklem Hastalik Cerrahisi 2014;25:165-7.

5. Asadollahi S, Shepherd D, Hau RC. Elbow fracture-dislocation combined with Galeazzi fracture in adult: A case report and literature review. Int J Surg Case Rep 2013;4:748-52.

6. Mezzadra A, Gusmeroli E, Tettamanzi M, Prestianni B, Molinari D. A rare injury to the upper limb: elbow dislocation combined with Galeazzi fracture-dislocation. Ital J Orthop Traumatol 1991;17:567-72.

7. Rajeev A, Senevirathna S, Harrison J. Subacute dislocation of the elbow following Galeazzi fracture-dislocation of the radius: A case report. J Med Case Rep 2011;5:589.

8. Shiboi R, Kobayashi M, Watanabe Y, Matsushita T. Elbow dislocation combined with ipsilateral Galeazzi fracture. J Orthop Sci 2005;10:540-2.

9. Nanno M, Sawaizumi T, Takai S. Case of bilateral Galeazzi fractures associated with dislocation of the right elbow. J Nippon Med Sch 2011;78:384-7.

10. Sarup S, Bryant PA. Ipsilateral humeral shaft and Galeazzi fractures with a posterolateral dislocation of the elbow: a variant of the "floating dislocated elbow". J Trauma 1997;43:349-52.

11. $\mathrm{Ng} \mathrm{Vy}$, Rose S. Combined elbow fracture-dislocation and Galeazzi fracture in an adult: a case report and review of the literature. Current Orthopaedic Practice 2010;21:330-3. 